\title{
Biopsy of the Right Ventricle
}

National Cancer Institute

\section{Source}

National Cancer Institute. Biopsy of the Right Ventricle. NCI Thesaurus. Code C80412.

Removal of tissue from the right ventricle for microscopic examination. 